\title{
THE EFFECTS OF EXPOSURE TO ORGANOPHOSPHOROUS COMPOUNDS ON SOME ASPECTS OF CARBOHYDRATE METABOLISM IN Tilapia zillii
}

\author{
Abdel-Salam Mohamed Ibraik Ohaida*, Nuha Mahmoud A. Akrawee** Zoology \\ Department. Faculty of Science. University of 7 October Misurata*, \\ High Institute of Medical Technology, Misurata**
}

\begin{abstract}
The Effect of organophosphorous insecticides compounds (Malathion and Fenitrothion) on certain aspects of carbohydrate metabolism in the freshwater fish Tilapia zillii exposed to $1 / 3$ $\mathrm{LC}_{50}$ of both insecticides for 96 hours was studied. Organophosphorous compounds were found to affect some parameters of carbohydrate metabolism. Muscle and liver glycogen decreased significantly accompanied with significant increase of the plasma glucose and the specific activity of phosphorylase enzyme in both liver and muscles. The activity of Succinate dehydrogenase (SDH), lactate dehydrogenase (LDH) and malate dehydrogenase (MDH) showed a significant decrease in liver and muscle tissues. Alanine transferase (ALT) and Aspartate transferase (AST) in liver and muscles also showed a significant decrease. Significant alterations in the content of metabolites and enzyme activity under malathion and fenitrothion toxicity seemed to suggest marked shift from aerobic to anaerobic condition.
\end{abstract}

\section{Introduction}

The use of organophosphorous pesticided is increasing progressively to control a wide variety of agricultural pests due to inability of insects to develop resistance against them (AL-Hamed,1967). However, pesticides used in or near aquatic ecosystems against the target organisms, enter the water bodies causing toxic effects on freshwater fish. Stressful situations in fish elicit neuroendocrine responses since both olamines (Nakano and Tomlinson, 1967) and adrenocorticoids (wedemeyer, 1969 and Danasoury et al., 1992) are secreted in increased amounts due to stress which cause a depletion of energy stores and induce disturbance in carbohydrate metabolism (Mazeaud et al., 1977).

The toxicity of organophosphorous compounds on fish in the present study undertaken as one of a series, dealing with the effects of organophosphorous compounds on fish physiology and biochemistry. Hence, this study was carried out to determine the effects of exposure to sublethal concentrations of malathion and fenitrothion in Tilapia zillii.

\section{Materials and Methods}

\section{Animal sampling and treatment manipulation :}

Tilapia zillii obtained from Tawarga pond and transported immediately to the fish laboratory conditions and kept for at least two weeks in 60 liters glass aquaria. They were fed on fish food (1\% crude fibre, $7 \%$ ash, $54 \%$ nitrogen free extract and recommended catecholamins and minerals) at 10 a.m. The water in the rearing aquaria was renewed daily.

Results of preliminary toxicity tests in the laboratory under static conditions, showed that $9 \mathrm{mg} / \ell$ and $3.5 \mathrm{mg} / \ell$ are the $\mathrm{LC}_{50}$ for fenitrothion and malathion respectively. Bome of the physico-chemical characteristics of the experimental water were as follows: temperature $24 \pm 1 . \mathrm{C}, \mathrm{pH}$ 7.5 , unity $0.19 \%$, and dissolved oxygen 8.0 ppm. A 12 hrs photoperiod was maintained.

For studying the effect of malathion and fenitrothion groups of 10 fish were exposed to sublethal concentration representing $1 / 3$ of the $\mathrm{LC}_{50}$ for both 
compounds. Water in aquaria was renewed daily and a fresh solution of tested compounds was added to bring the concentration to the desired level. The control group for malathion tests did not receive any chemical whereas that for fenitrothion received $3 \mathrm{mg} / \mathrm{l}$ acetone since the standard stock solution of fenitrothion was prepared in acetone as a solvent.

\section{Tissues sample collection}

After treatment, fish were anaesthetized in 3-aminobenzoate (MS222 solution). While muscle and liver tissues were isolated immediately, weighed and homogenized in isotonic solution of $\mathrm{KCl}$ and centrifuged at $15000 \mathrm{rpm}$ for $10 \mathrm{~min}$ at $4 \circ \mathrm{C}$ and supernatant was used for enzyme assay. Glycogen content of both tissues was determined using amyloglucosidase enzyme method by Keppler and Decker (1974). Plasma glucose concentration was determined by using GOD-period method (Biochemica test combination Boehringer Mannheim GmbH, Germany). Enzyme activities were measured in liver and muscles according to Bergmeyer (1974). Protein in homogenates was estimated by the method of Lowry et al., (1951). For statistical evaluation the mean (x) and the standard deviation (SD) were calculated for each test group. Data were statistically analysed using student t-test at 0.05 significant level (Snedccor and Cochran, 1980).

\section{Results and discussion:}

The data presented in Table 1 show that the activities of AST are lower in muscles than in liver during the experiment. AST and ALT activities are increased in liver and muscle of Tilapia zillii after exposure to $1 / 3 \quad \mathrm{LC}_{50}$ of malathion and fenitrothion for 96 hours. The percentage increase in AST activity was $39.3 \%$ and $42.3 \%$ in liver and $78.6 \%$ and $89.4 \%$ in muscles of fish exposed to malathion and fenitrothion respectively. The percentage increase of ALT activity was $39 \%$ and $40 \%$ in liver and $47.8 \%$ and $57.5 \%$ in muscles of fish exposed to malathion and fenitrothion respectively. The present results agreed with the finding of Reda (1992) and Prasada Rao and Ramana Rao (1984) who showed that AST and ALT activities were elevated in liver and muscles of Cyprimus carpio and $\mathrm{T}$. mossambica during organophosphorous compounds ( methyl parathion and fenitrothion) stress.

AST and ALT play an important role in regulating protein and carbohydrate metabolism. Elevation of AST and ALT in the present study suggests active transferetion of $\alpha$ amino acids to keto acids which could be used for energy production.

Table 1 shows that phosphorylase enzyme activity in Tilapia zillii liver tissue is higher than the phosphorylase enzyme activity in muscle tissue. In the present study, a $96 \mathrm{hrs}$ exposure of Tilapia zillii to $1 / 3$ of $\mathrm{LC}_{50}$ for malathion and fenitrothion produced a significant increase in phosphorylase enzyme activity in liver and muscle tissues with a percent increase of $26 \%, 33 \%, 43 \%$ and $32.5 \%$ respectively. These results are in agreement with those of Reda (1992) who found that methyl parathion and fenitrothion cause a rise in phosphorylase activity in the carp Cyprinus carpio.

In the present study, it was found that exposure of Tilapia zillii to $1 / 3 \mathrm{LC}_{50}$ of malathion and fenitrothion resulted in a 32.8 and $36.8 \%$ decrease in liver glycogen respectively. However, glycogen decrease in muscle tissue of fish exposed to $1 / 3 \mathrm{LC}_{50}$ of malathion and fenitrothion for $96 \mathrm{hrs}$, caused a significant increase of $40 \%$ and $58 \%$ respectively. The relative reduction of muscle glycogen was higher than that of liver. This may be due to the gluconeogenesis process in liver from protein which was higher, thus, confirming the previous findings of Reda (1992) in Cyprinus carpio and Danasoury et al.(1997) in Oreochromis niloticus .

Furthermore, the results in the present study indicated that the percentage increase in blood glucose level of fish exposed for $96 \mathrm{hrs}$ to $1 / 3 \mathrm{LC}_{50}$ malathion and fenitrothion was 21 and 38 respectively (Table, 1). Similar increase was reported by Koundinya and Ramamaurthi (1979), who found that blood glucose level increased in Tilapia mossambica exposed to $\mathrm{LC}_{50}$ of 
fenitrothion. Reda (1992) recorded hyperglycemia in Cyprinus carpio exposed to methyl malathion and fenitrothion and pointed out that the increase in plasma glucose was due to breakdown of hepatic glycogen. On the other hand, Moorthy et al. (1985) concluded that the elevation of blood glucose in fish (Lamellidens marginalis) exposed to methyl parathion was due to reduction of glucose oxidation in citric acid cycle. While the mode of action of organophosphorous compounds is acetylcholinestrase inhibition, then the acetylcholine level increased leading to secretion of cateholamins which through adenylcyclase system can raise the level of cyclic AMP affecting the activity of enzymes involved in glycogenolysis (Nakano and Tomlinson, 1967 and Brzezinski and Ludwicki, 1973). In addition cortisol as an unspecific parameter which increases in response to stress phenomena such as pollutants (Grant and Mehrle, 1973, Gluth and Hanke, 1983, 1984; Schwarz, 1988; Danasoury et al., 1992) indirectly caused glycogen breakdown (Heath, 1995) and enhanced transferase enzymes resulting in hyperglycemia. The present results suggest that the decrease of glycogen in liver and muscles may be due to the increase of phosphorylase activity in liver and muscles, and elevation of glucose level after malathion and fenitrothion exposure confirm the view that the increase of blood glucose level is due to glucogenolysis stimulation.

Regarding the effect of $1 / 3 \mathrm{LC}_{50}$ of malathion after $96 \mathrm{hrs}$ exposure on liver $\mathrm{MDH}, \mathrm{SDH}$ and $\mathrm{LDH}$, the results indicated that percentage of inhibition activity was 19.4, -11 , and -31 for MDH, SDH and LDH respectively, while the percentage inhibition of MDH, SDH and LDH was -17, -13 , and -36 respectively in case of fenitrothion exposure.

In the case of muscle tissue after exposure to $1 / 3 \quad \mathrm{LC}_{50}$ of malathion for 96 hrs, a significant inhibition in the activity of MDH, SDH was recorded (-14 and -23 respectively).

However, LDH activity showed an increase by $+36 \% \mathrm{MDH}$ and SDH activity was inhibited by $16 \%$ and $26 \%$ respectively in muscles of fish exposed to fenitrothion.

The results of the present study revealed that the activity of mitochondrial enzymes like SDH and MDH is decreased in fish exposed to both tested compounds. These results are in agreement with those of Koundinya and Ramaurthi (1979), Kabeer et al. (1984) working on Tilapia mossambica. The inhibition of NAD dependent, LDH activity and SDH activity indicated a decreased pass of intermediates into the citric acid cycle. This might be responsible for suppression of oxidative phase of tissue metabolism under O.P impact showing a shift from aerobic metabolism to anaerobic metabolism under pesticide stress. This suggestion is supported by Hiltibran (1974) who reported a diminished $\mathrm{O}_{2}$ uptake by blue gill liver mitochondria in the presence of organophosphate. The increase of muscle LDH activity was due to the choice of the red muscles which is aerobic and which contains the myoglobin pigment (Prasada and Ramana,1979).

\section{References:}

Al-Hamed M I (1967). Crab culture in the Republic of Iraq. F. A. O Fish. Rep., 44 (2): 135-142.

Bergemeyer H V (1974). Methods of enzymatic analysis Varlag Chemi., Weinheim, $2^{\text {nd }}$ ed. Vol. 3. Academic press, NewYork. 1196-1201.

Brzezinski J and Ludwicki K (1973). The interrelationship of the changes of acetylcholinesterase and catecholamines, blood and urine levels in rats poisoned with disyston. Pol. Pharmacol. Pharm., 25: 313-317.

Danasoury M A K; Abd El-Baki M A and Reda L (1992). The effect of pentachlorophenol and atrazine on cortisol levels and carbohydrate metabolism of Nile tilapia ( Oreochromis niloticus) Egypt. J. Appl. Sci., 7 (3): 615-626.

Danasoury M A K; Reda L A; Shoukry A and Kayomy F (1997). Some physiological effects of sublethal concentration of baylucide and malathion on Nile tilapia fish Oreochromis niloticus. Egypt. J. Appl. Sci.,12 (2): 10-30.

Gluth G and Hanke W (1983). The effect of temperature on physiological changes in carp, 
Cyprinus carpio L., induced by phenol. Ecotoxicol. And Environ. Safety, 7: 373-389.

Gluth G and Hanke W (1984). A comparison of physiological changes in carp, Cyprinus carpio L. induced by several pollutants at sublethal concentration. II-The dependency on the temperature. Comp. Biochem. Physiol., 79c,(1): 39-45.

Grant B F and Mehrle P M (1973). Endrin toxicosis in rainbow trout

(Salmo gairdneri). J. Fish. Res. Board Can, 30: 31-40.

Heath A G (1995). Water pollution and Fish physiology ( $2^{\text {nd }}$ ed), Lewis publishers CCR Boca Raton, New York, London and Tokyo.

Hiltibran R C (1974). Oxygen and phosphate metabolism of blue gill liver mitochondria in the presence of some insecticides, Trans. III State Acad. Sci. 67: 228-234.

Kabeer A S; Parasada Rao K S; Sambasira Rao and Ramana Rao K V (1984). Sublethal toxicity of malathion on the proteases and free amino acid compostion in the liver of the teleost Tilapia mossambica. Toxicology Letters, 20:59-62.

Keppler D and Decker K (1974). Glycogen determination with amyloglucosidase In: Bergmeyer, H. V. Verlag Chemie, ed. "Methods of Enzymatic Analysis" (Weinheim) $2^{\text {nd }}$ Enhlish Ed., pp. 1127-1131.

Koundinya P R and Ramaurthi R (1979). Effect of organophosphate pesticide sumithion (Fenitrothion) on some aspects of carbohydrate metabolism in a freshwater fish, Sarotherodon (Tilapia) mossambica (peters). Experientia 35, Birkhauser verlag, Basel (Schweiz): 1632-1633. Lowry O H; Rosebrough R J; Farr A L and Randall R J (1951). Protein measurement with the folin phenol reagent. J. Biol. Chem. 193: 265-275.
Mazeaud M M; Mazeaud F and Donaldson E M (1977). Primary and secondary effects of stress in fish. Some new data with general review. Trans. Am. Fish Soc., 106, 201-212.

Moorthy K S; Reddy K; Swami K S and Chetty C S (1985). Glucose metabolism in hepatopancreas and gill of Lamellidens marginalis during methyl parathion toxicity Pesticides. Bioch and Physiol., 24: 40-44.

Nakano T and Tomlinson N (1967). Catecholamines and carbohydrate concentrations in rainbow trout (Salmo gairdneri) in relation to physical disturbance. J. Fish. Res. Board Can, 24: 1701-1715.

Prasada Rao K S and Ramana Rao K V (1984). Tissue specific alteration of aminotransferase and total ATPase in the fish (Tilapia mossambica) under methyl parathion impact. Toxicology, Letters, 20: 53-57.

Reda L A (1992). Physiological effects of some pollutants on fish. Ph.D. Thesis, Suez Canal University, Ismailia, Egypt.

Samuel N and Sastry K V (1989). In vivo effect of monocrotophos on the carbohydrate metabolism of the freshwater snake head fish, Chama punctatus. Pesticide Bioch and physiol., 34: 1-8.

Schwarz E (1988). Untersuchungen zu wechsel wirkungen von schadstoffen und hormonen Bein Karpfen ( Cyprimus carpio L. ) Dissertation Fakulitat fur Bio-und Geowissenschaften der University Karlsruhe, Germany.

Snedecor C W and Cochran W G (1980). Statistical methods, $7^{\text {th }}$ Ed. Allied Pacific Bombay.

Wedemeyer G (1969). Stress-induced ascorbate depletion and cortisol production in two salmonid fishes. Comp. Biochem. Physiol, 29: $1247-1251$. 
Table 1: Effect of exposure to organophosphorous compounds (1/3 $\mathrm{LC}_{50}$ of fenitrothion and $1 / 3$ $\mathrm{LC}_{50}$ of malathion) on some enzymological parameters and carbohydrate metabolites in tilapia zillii.

\begin{tabular}{|c|c|c|c|c|c|c|c|}
\hline \multirow[b]{2}{*}{ Tissues } & \multirow[b]{2}{*}{ Parameters } & \multicolumn{3}{|c|}{ Malathion } & \multicolumn{3}{|c|}{ Fenitrothion } \\
\hline & & Control & treated & $\%$ & Control & treated & $\%$ \\
\hline \multirow{7}{*}{ Liver } & Phosphorylase $^{\mathrm{A}}$ & $8.30^{a} \pm 0.16$ & $12.10^{\mathrm{a}} \pm 1.00$ & +46.0 & $6.48^{b} \pm 1.70$ & $8.30^{a} \pm 0.16$ & +33.0 \\
\hline & $\mathrm{MDH}^{\mathrm{B}}$ & $1.60^{g} \pm 0.13$ & $1.29^{g} \pm 0.10$ & -19.4 & $1.58^{\mathrm{h}} \pm 0.14$ & $1.31^{\mathrm{h}_{ \pm}} 0.10$ & -17.0 \\
\hline & $\mathrm{SDH}^{\mathrm{B}}$ & $1.40^{\mathrm{c}} \pm 0.10$ & $1.25^{\mathrm{c}} \pm 0.05$ & -11.0 & $1.39^{\mathrm{d}} \pm 0.01$ & $1.21^{\mathrm{d}} \pm 0.01$ & -13.0 \\
\hline & $\mathrm{LDH}^{\mathrm{B}}$ & $1.22^{\mathrm{e}} \pm 0.11$ & $0.84^{\mathrm{e}} \pm 0.13$ & -0.31 & $1.18^{\mathrm{r}} \pm 0.01$ & $0.78^{\mathrm{r}} \pm 0.09$ & -36.0 \\
\hline & $\mathrm{AST}^{\mathrm{C}}$ & $29.56^{\mathrm{i}} \pm 0.2$ & $41.17^{\mathrm{i}} \pm 0.18$ & +39.3 & $29.42^{\mathrm{j}} \pm 0.16$ & $41.87^{\mathrm{j}} \pm 0.09$ & +42.3 \\
\hline & $\mathrm{ALT}^{\mathrm{C}}$ & $42.13^{\mathrm{k}} \pm 0.1$ & $58.56^{\mathrm{k}} \pm 0.28$ & +39.0 & $43.57^{1} \pm 0.1$ & $61.0^{1} \pm 0.15$ & +40.0 \\
\hline & Glycogen $^{\mathrm{D}}$ & $67.80^{\mathrm{m}} \pm 1.2$ & $45.56^{\mathrm{m}} \pm 2.0$ & -32.8 & $67.4^{\mathrm{n}} \pm 1.1$ & $42.6^{\mathrm{n}} \pm 1.8$ & -36.8 \\
\hline \multirow{7}{*}{ Muscle } & Phosphorylase $^{\mathrm{A}}$ & $4.50^{\mathrm{a}} \pm 0.31$ & $6.49^{a} \pm 0.36$ & +43.0 & $4.64^{b} \pm 0.41$ & $6.1^{\mathrm{a}} \pm 0.41$ & +32.5 \\
\hline & $\mathrm{MDH}^{\mathrm{B}}$ & $1.71^{\mathrm{g}} \pm 0.18$ & $1.46^{\mathrm{g}} \pm 0.08$ & -14.0 & $1.68^{\mathrm{h}} \pm 0.1$ & $1.44^{\mathrm{h}} \pm 0.07$ & -16.0 \\
\hline & $\mathrm{SDH}^{\mathrm{B}}$ & $1.39^{c} \pm 0.01$ & $1.07^{\mathrm{c}} \pm 0.06$ & -23.0 & $1.41^{\mathrm{d}} \pm 0.17$ & $1.04^{\mathrm{d}} \pm 0.08$ & -26.0 \\
\hline & $\mathrm{LDH}^{\mathrm{B}}$ & $2.44^{\mathrm{e}} \pm 0.13$ & $3.05^{\mathrm{e}} \pm 0.15$ & +25.0 & $2.44^{\mathrm{r}} \pm 0.17$ & $3.16^{\mathrm{r}} \pm 0.02$ & +30.0 \\
\hline & $\mathrm{AST}^{\mathrm{C}}$ & $10.58^{\mathrm{i}} \pm 0.3$ & $18.9^{\mathrm{i}} \pm 0.18$ & +78.6 & $10.61^{\mathrm{j}} \pm 0.2$ & $20.1^{\mathrm{j}} \pm 0.16$ & +89.4 \\
\hline & $\mathrm{ALT}^{\mathrm{C}}$ & $29.11^{\mathrm{k}} \pm 0.2$ & $43.03^{\mathrm{k}} \pm 0.11$ & +47.8 & $29.3^{1} \pm 0.2^{1}$ & $46.16^{1} \pm 0.27$ & +57.5 \\
\hline & Glycogen $^{\mathrm{D}}$ & $7.8^{\mathrm{m}} \pm 0.30$ & $4.7^{\mathrm{m}} \pm 0.30$ & -40.0 & $7.6^{n} \pm 0.3$ & $3.2^{\mathrm{n}} \pm 0.3$ & -58.0 \\
\hline \multicolumn{2}{|c|}{ Serum glucose } & $63.01 \pm 1.2$ & $80.02 \pm 1.4$ & \pm 21.0 & $63.03 \pm 1.0$ & $87.01 \pm 2.0$ & \pm 38.0 \\
\hline
\end{tabular}

Note: Values in the same row having the same superscript are significantly different $(\mathrm{P}<0.05)$; mean $\pm \mathrm{SD} ;(+)=$ increase $;(-)=$ decrease.
A: $\mathrm{mg} / \mathrm{g}$ fresh weight
B: $\mu \mathrm{g}$ formazan $/ \mathrm{mg}$ protein $/ \mathrm{hr}$
$\mathrm{C}$ : unit/mg protein/min
D: $\mu \mathrm{g}$ glycocyl $/ \mathrm{mg}$ tissue
E: $\mathrm{mg} / 100 \mathrm{ml}$ 


\title{
تأثير المركبات الفوسفورية على بعض مظاهر ايض الكربوهيدرات في اسماك
}

\section{Tilapia zillii البلطي}

\author{
عبد السلام محمد ابريك اوحيده \\ قسم علم الحيوان ـ كلية العلوم- جامعة السابع من أكتوبر - مصرتة_ـ ليبيا

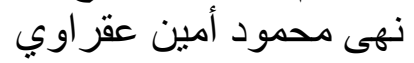 \\ قسم تقنية وصحة البيئة ـ المعهد العالي للتقنية الطبية ـ مصر اتة ـ ليبيا
}

عرضت اسماك البلطى Tilapia zillii لنلث التركيز المميت لنصف الإفر اد لكل من المركبين العضويين الفوسفوريين المختبرين ( الملاثيون ، الفنتروثيون) لمدة 96 ساعة فأحدثت التغير ات التالية:-

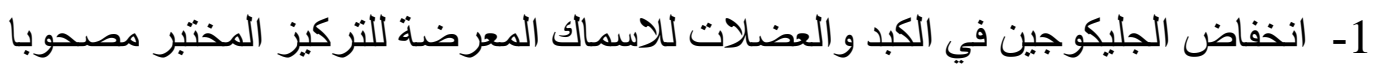

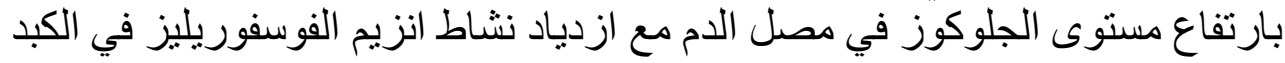



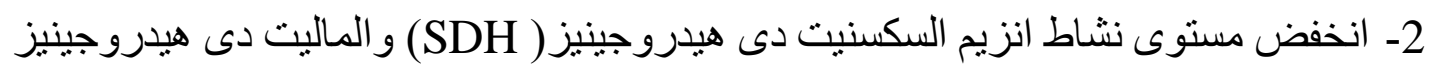

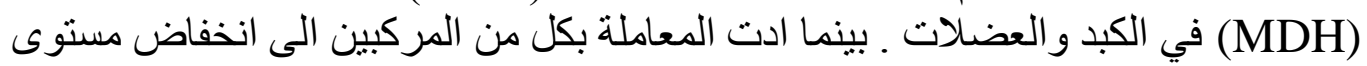

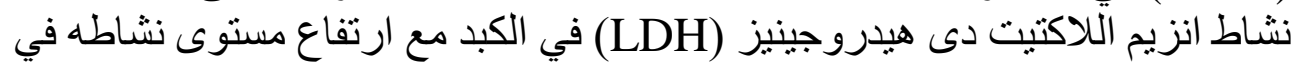
العضلات لكل من المركبين المختبرين.

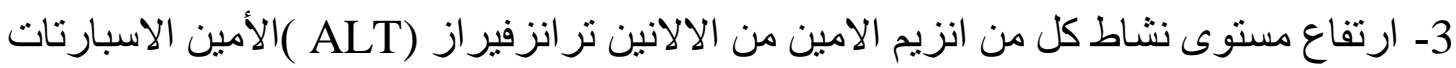


في كل القياسات السابقة. توحى نتائج الدراسة بان كل من المركبين الفوسفوريين ( الملاثيون ، الفنتروثيون) يؤديان الى الى الفي

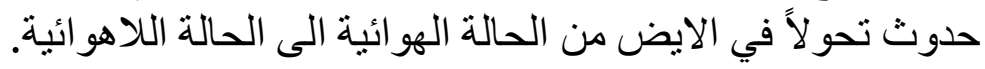

